\title{
A new species of Megaselia Rondani (Diptera: Phoridae) associated with one sex of a dioecious fig tree in Thailand
}

\author{
R. Henry L. DISNEY ${ }^{1}$ and Stephen G. COMPTON ${ }^{2}$ \\ ${ }^{I}$ Department of Zoology, University of Cambridge, Cambridge CB2 3EJ, UK; e-mail: rhld2@hermes.cam.ac.uk \\ (corresponding author) \\ ${ }^{2}$ School of Biology, University of Leeds, Leeds, LS2 9JT, UK; e-mail: S.G.A.Compton@leeds.ac.uk
}

\begin{abstract}
Megaselia ischnopodae Disney n. sp. (Diptera, Phoridae) is reared from larvae found in mature male figs of Ficus ischnopoda Miq. (Urticales, Moracea) in Thailand. Other phorid species associated with fig trees are briefly reviewed.
\end{abstract}

Key words: scuttle flies, Agaonidae, Ficus ischnopoda, riparian forest, Oriental, Southest Asia

\section{INTRODUCTION}

Figs (syconia) are the unique enclosed inflorescences of fig trees (Ficus L., Urticales: Moraceae). Fig trees are pollinated by adult female fig wasps (Hymenoptera, Agaonidae) that enter receptive figs via a narrow ostiole to lay eggs in the numerous ovules that line their inner surfaces. Wingless adult males of the next generation emerge more or less synchronously a few weeks later. They seek out and mate with females that are still inside the ovules, then act cooperatively to chew one or more emergence tunnels through the wall of the fig. This is often through the ostiole. The females then either actively or passively collect pollen and fly off in search of receptive figs to enter. Around half of the 800 or so described species of fig trees have a monoecious breeding system, where pollinator offspring and seeds develop together in the same figs. The remaining fig tree species have a functionally dioecious breeding system, where 'male' trees have figs that support development of fig wasps and 'female' trees produce only seeds.

Figs and the fig wasps that develop inside them are eaten by a wide range of other insects, including species from several families of flies: Cecidomyiidae, Drosophilidae, Lonchaeidae and Phoridae (Compton \& Disney 1991, Harry et al. 1997, Miao et al. 2011, MacGowan \& Compton 2018). Five species of Megaselia Rondani (scuttle flies, Phoridae) have been reared previously from nine different species of monoecious fig trees in South Africa (Compton \& Disney 1991). They are Megaselia dentata Disney, M. ficaria Disney, $M$. parvorata Disney, $M$. surophila Disney and $M$. vorata Disney. There was no evidence of any host tree specificity and it was thought that their larvae were preying upon the developing fig wasps. Adult females of $M$. vorata were observed actively capturing and then feeding on female pollinator fig wasps. The only other scuttle flies reported as developing in figs are three species of Chonocephalus Wandolleck, C. blackithorum Disney, species B and species C in Disney (1986), which could not be named because only the flightless females were reared. However, species $\mathrm{C}$ was subsequently linked to its male as $C$. aduncus Schmitz and one male $C$. adficus Disney was subsequently described. These were keyed by Disney (2016). Their larvae were probably feeding on yeasts. 


\section{MATERIAL AND METHODS}

Ficus ischnopoda is a shrub or small tree with a wide distribution across SE Asia where it grows mainly on rocks in and close to rivers (Berg \& Corner 2005). Figs from male and female trees were opened and the behavior of fly larvae inside was observed under a binocular microscope. The larvae pupated inside Petri dishes lined with moist filter paper. Emerged scuttle flies were preserved in 70\% ethanol and were slide mounted by RHLD in Berlese Fluid (Disney 2001). They are deposited in the University of Cambridge Museum of Zoology (UCMZ).

\section{Megaselia ischnopodae Disney n. sp.}

(Figs 1-24)

Diagnosis. In Borgmeier's (1967) key to Group VIII of Indo-Australian Megaselia it runs to couplet 14 lead 2 and to M. patelipya Borgmeier. However the figure of its hypopygium immediately excludes this species. At least five other species from elsewhere or subsequently described from Australasia will also run to this same couplet and lead. However, unlike M. patelipya they all have a dark brown thorax, darker legs and/or the hypopygium has hairs only.

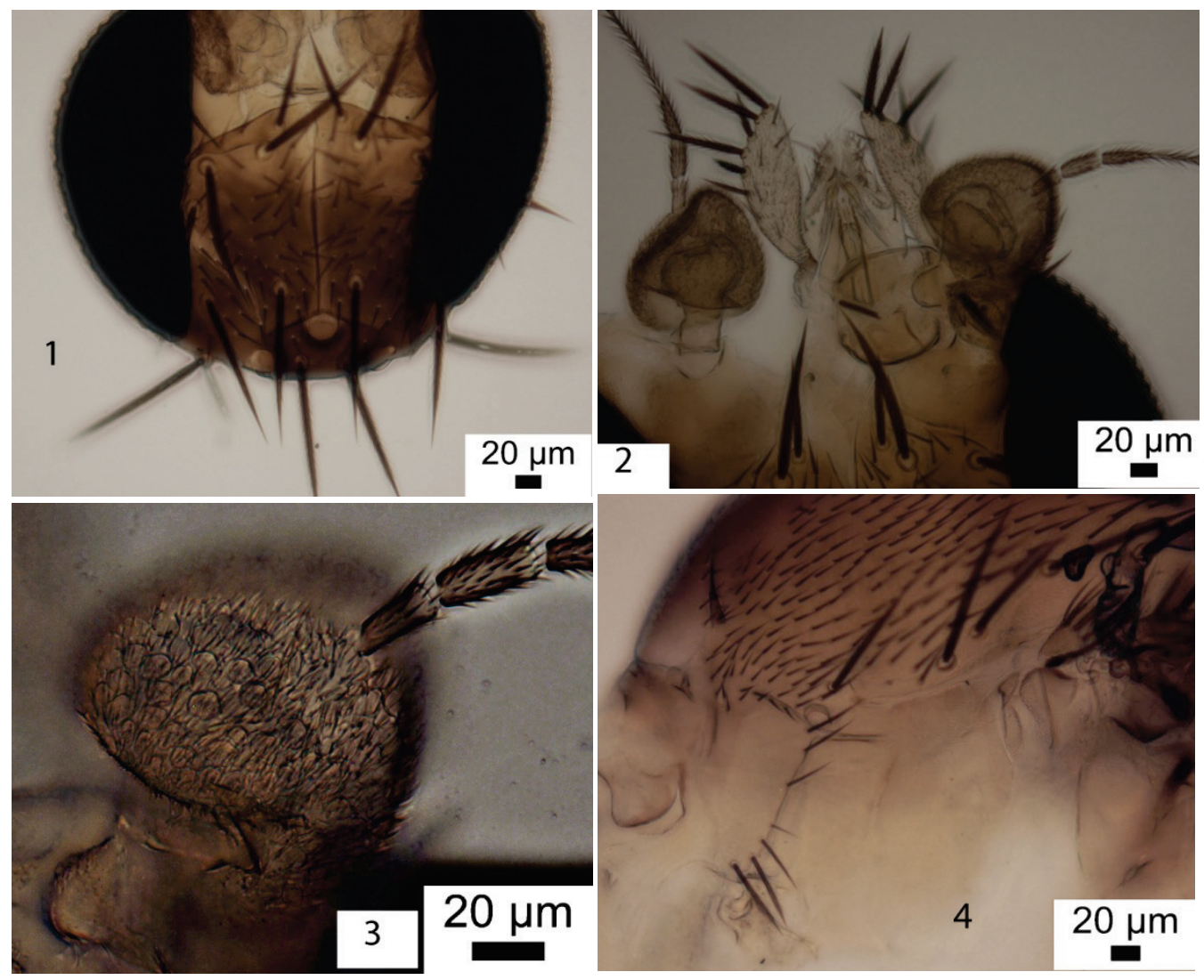

Figs 1-4. Megaselia ischnopodae n. sp. male: 1 - frons, 2 - antennae, palps and proboscis, 3 - postpedicel, 4 - left propleuron, notopleuron and mesopleuron. 


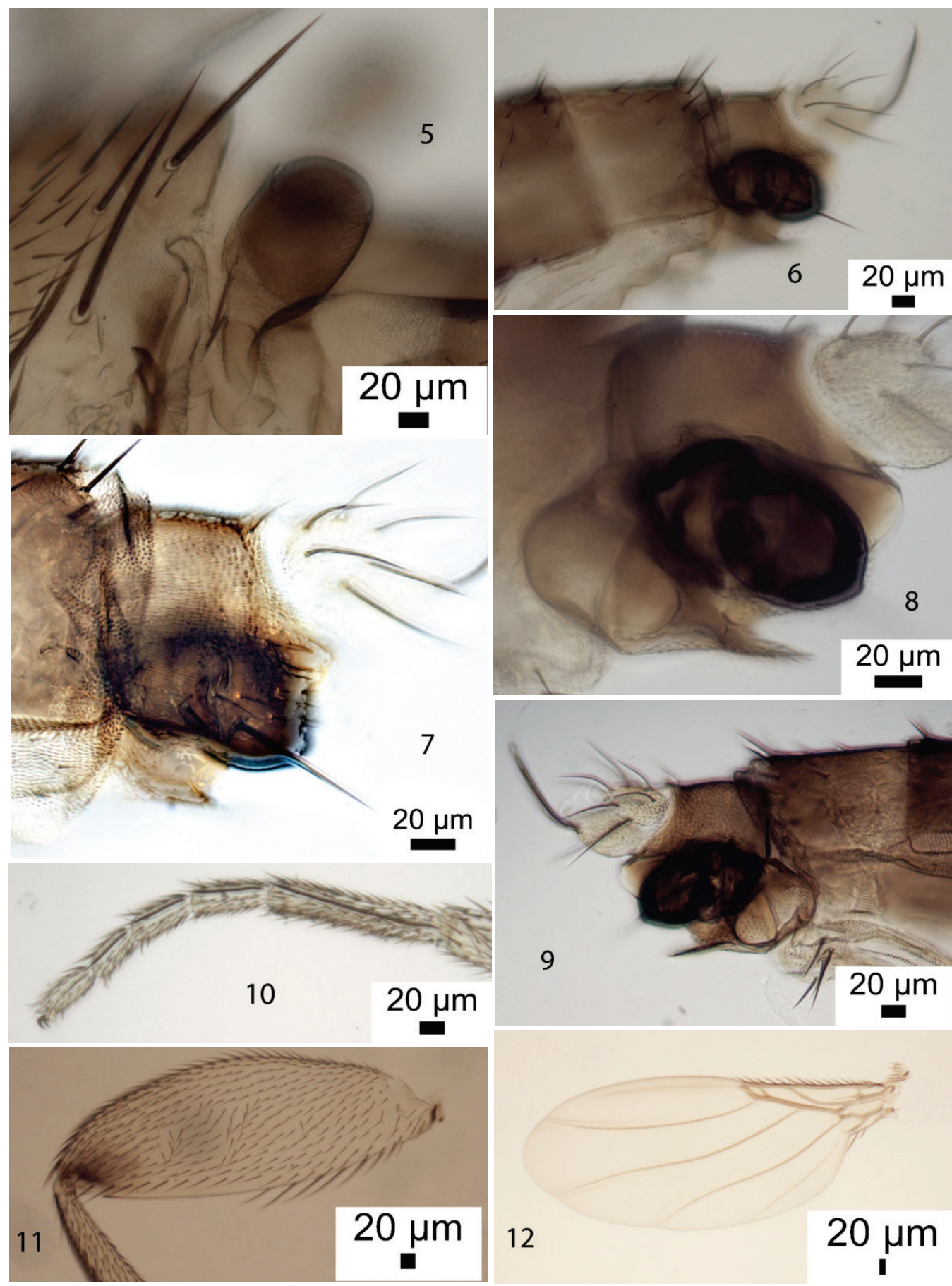

Figs 5-12. Megaselia ischnopodae n. sp. male: 5 - left side of scutellum and haltere, 6-8 - left side of hypopygium, 9 - right side of hypopygium, 10 - front tarsus, 11 - hind femur, 12 - wing. 
Male. Frons as Fig. 1, with dense fine microsetae, with lower supra-antennal bristles clearly shorter and finer than upper pair and the anterolateral bristles higher on the frons than the antials. Antennae, palps and proboscis as Fig. 2. Postpedicels with subcutaneous pit sensillae (Fig. 3). Cheek with 3 bristles and jowl with 2 that are longer and more robust. Thorax mainly yellow, with bare mesopleuron, 2 notopleural bristles each side and no notopleural cleft (Fig. 4). Scutellum with a minute hair and a pair of bristles each side (Fig. 5). Abdominal tergite 2 yellow in anterior two thirds, rest brown except T5 and T6 tend to be paler. Venter pale with hairs on segments 3-6, but those on 3 and 4 are small and few in number. Hypopygium as Figs 6-9, the epandrium having hairs and one bristle each side and the left hypandrial lobe is vestigial. The legs are yellow apart from a dark tip to hind femur. Front tarsus with posterodorsal hair palisades on segments 1 to 4 and 5 longer than 4 (Fig. 10). Dorsal hair palisade of mid tibia extends about 0.7 times it length. Hind femur as Fig. 11. Wings (Fig. 12) 1.1-1.2 mm long, costal index 0.39-0.40, costal ratios 3.8-3.9: 1.7-1.8 : 1 . Tip of vein Sc free. Costal cilia $0.05 \mathrm{~mm}$ long. No hair at base of vein 3 . With 2 axillary bristles, the outer being $0.08 \mathrm{~mm}$ long. Haltere with pale stem and brown knob (Fig. 5).

Female. Head as male but with smaller palps and a larger proboscis (Fig. 13). Thorax as male. Abdominal tergites $1-6$ as Fig. 14. Tergite 7 as Fig. 15 and tergite 8 and end of abdomen as Fig. 16. Sternite 7 and lobes at rear of sternum 8 as Fig. 17. Furca as Fig. 18. Dufour's crop mechanism as Fig. 19. Wings as Fig. 20, the costal index being 0.41 and the costal ratios 5.75.9: 2.6-2.7: 1. Otherwise as male.

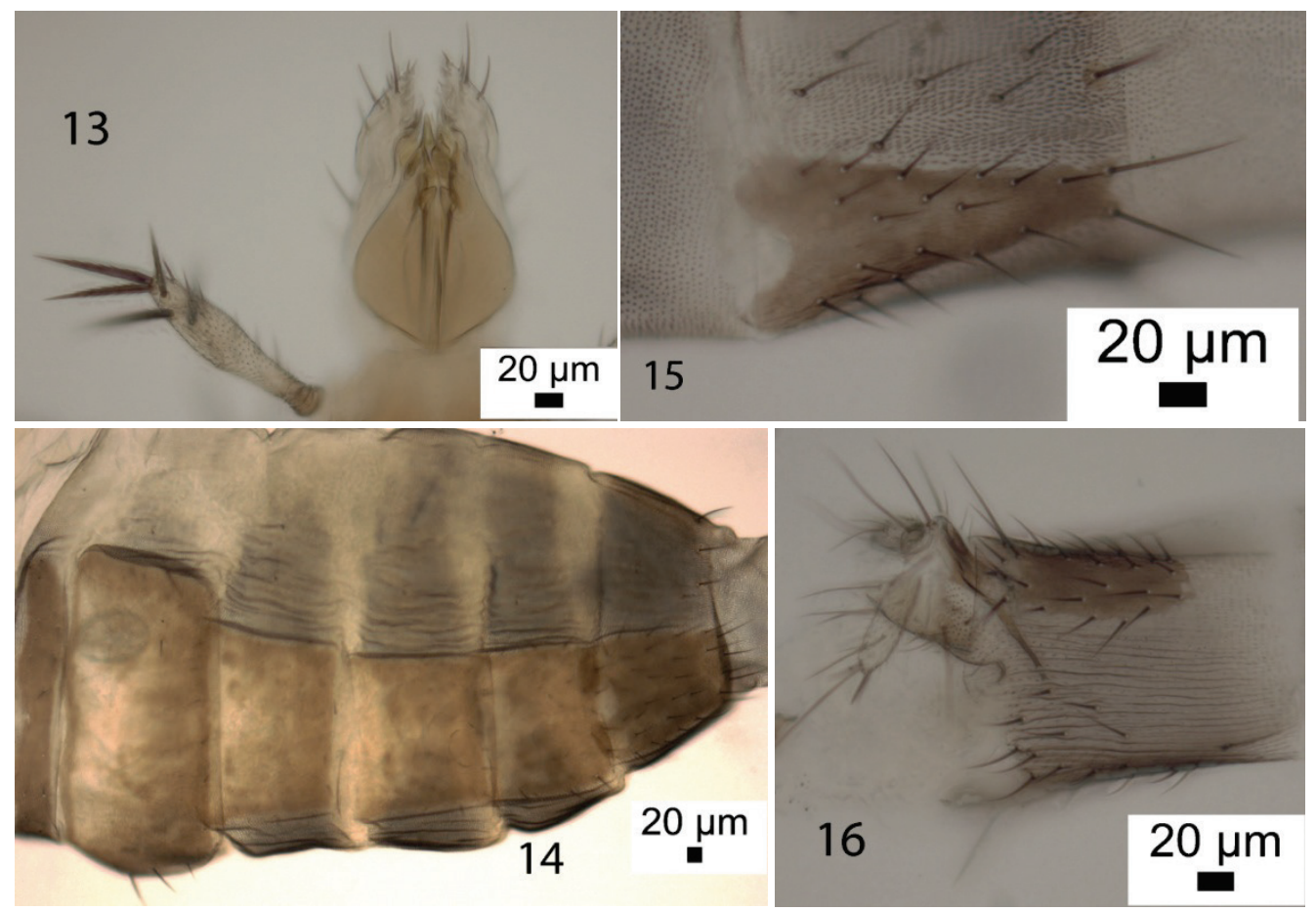

Figs 13-16. Megaselia ischnopodae n. sp. female: 13 - palp and proboscis, 14 - abdominal tergites 1-6, 15 - tergite 7, 16 - tergite 8 and end of abdomen.

Puparia. Only moderately sclerotized (Fig. 21). Anterior cap as Fig. 22 and rear end as Fig. 23. Left eclosion plate as Fig. 24. 

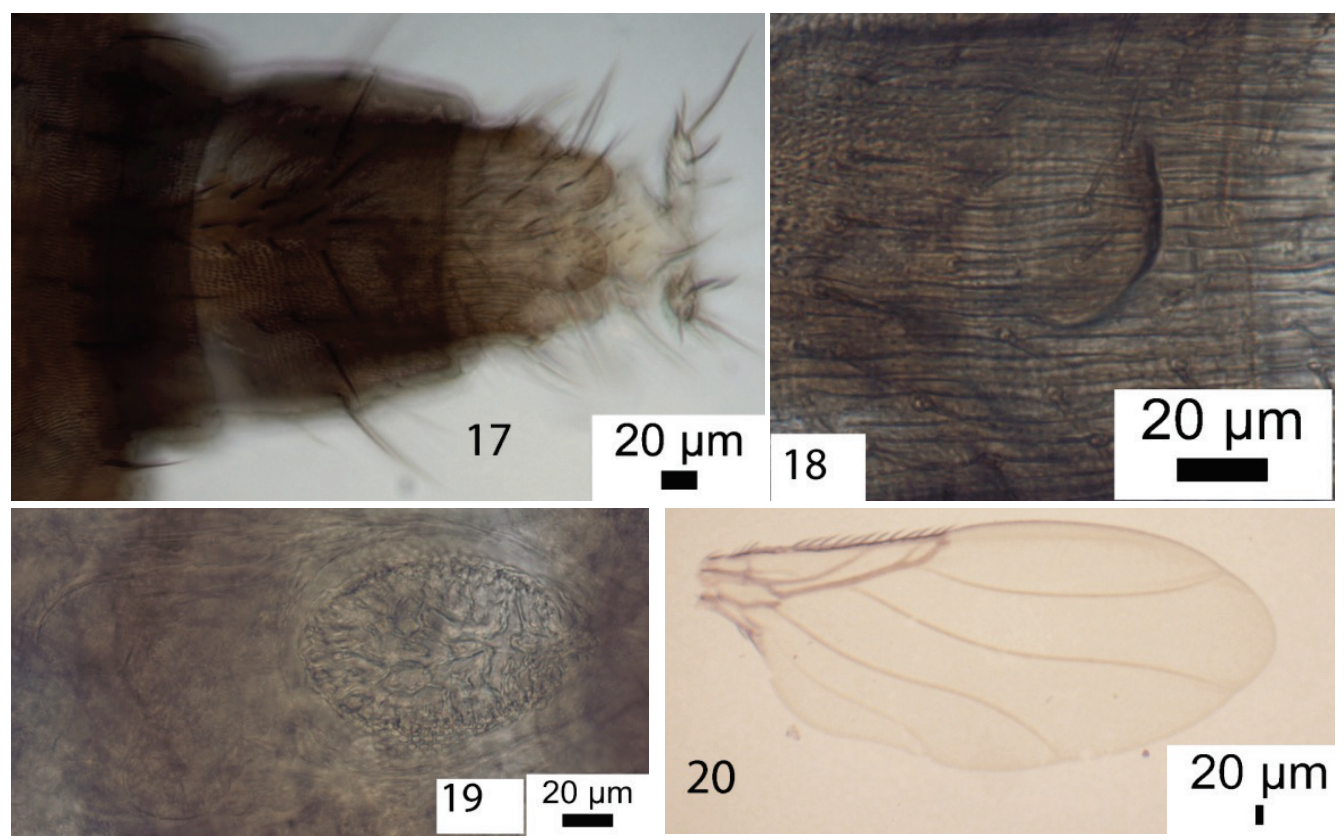

Figs 17-20. Megaselia ischnopodae n. sp. female: 17 - sternite 7 and rest of abdomen, 18, - furca, 19 - Dufour's crop mechanism (anterior end to right), 20 - wing.
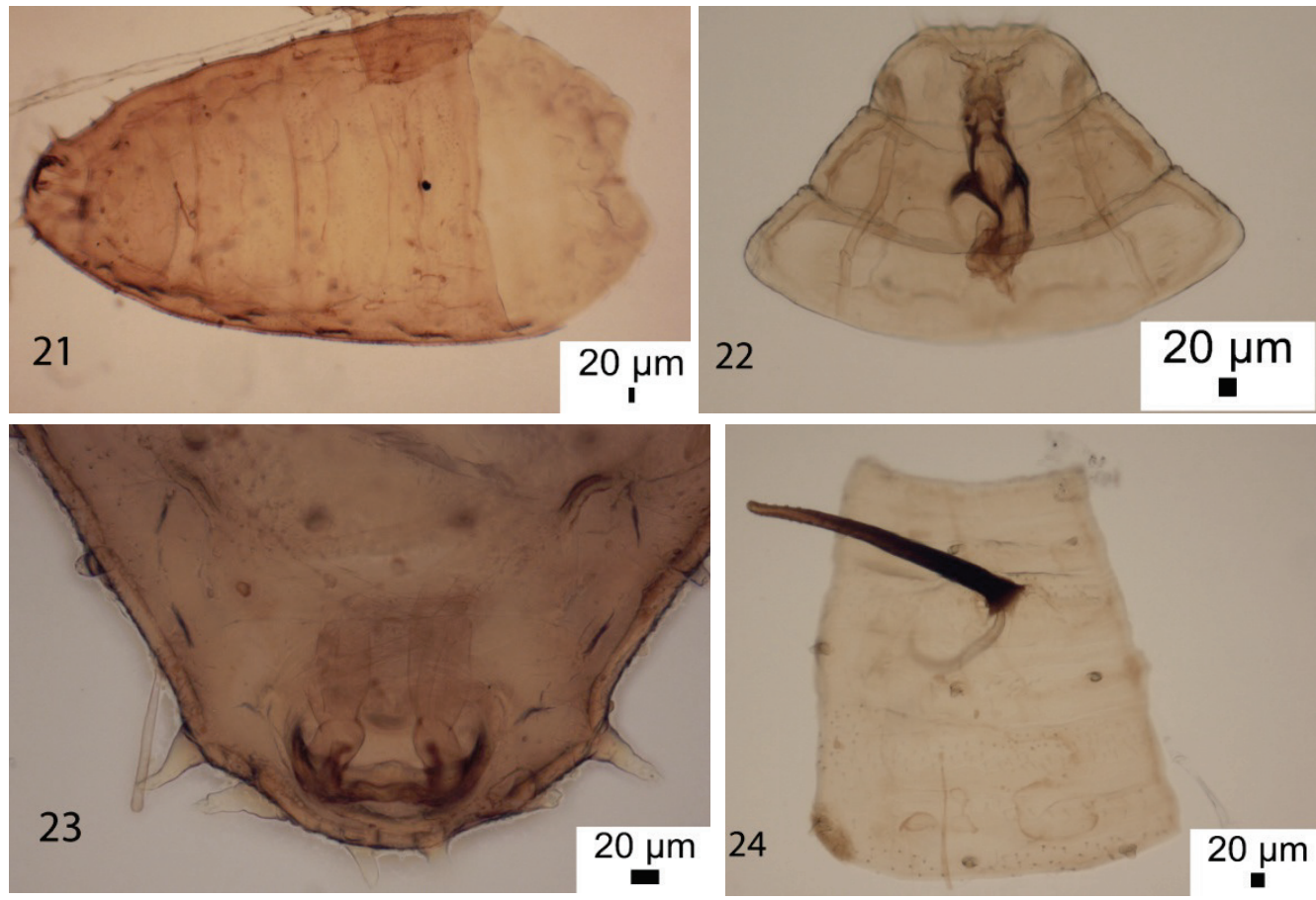

Figs 21-24. Megaselia ischnopodae n. sp. puparium: 21 - general appearance, 22 - anterior cap, 23 - rear end, 24 - left eclosion plate. 
Material examined. Holotype male, Thailand, Erawan National Park, Erawan Waterfalls, March 2018, reared from male figs of Ficus ischnopoda Miq. S. G. Compton (UCZM, 6-45). Paratypes 4 males, 5 females as holotype. 7 puparia.

Etymology. Named after the fig species.

\section{DISCUSSION}

Examination of mature figs obtained from male and female $F$. ischnopoda trees detected two distinct dipteran larvae crawling inside the male figs. No larvae were present in the female figs that were examined. The larger larvae were Silba ischnopoda MacGowan, 2018 (MacGowan \& Compton 2018) and the smaller larvae belonged to the phorid described here. Tiny mites (provisionally identified as Tarsonemidae) were also present inside some of the male figs. Mature female figs contained seeds, whereas the mature male figs with the fly larvae contained dehiscing anthers and living and dead adult male pollinator fig wasps that had developed within the figs. Most of the females had already emerged through the ostiolar exit tunnels cut by the males. Unlike many Ficus species, F. ischnopoda is a passively pollinated fig tree (Jousselin \& Kjellberg 2001, Berg \& Corner 2005) that needs to have many male flowers in order to ensure pollination. The male flowers occupy the area near the ostiole of the male figs, whereas the female flowers where fig wasp offspring develop is located towards the base of the figs. The phorid larvae were present among these female flowers, suggesting that they were feeding on dead and dying adult male fig wasps, rather than the pollen that was being released by the dehiscing anthers. The presence of the phorid larvae inside figs where the fig wasps had cut an exit hole through the ostiole suggests that they may routinely use this to gain entry to the interior, and small phorid larvae were observed on the outside of the ostioles of slightly less mature male figs, where no exit hole was present.

\section{ACKNOWLEDGEMENTS}

RHLD's work on Phoridae is currently funded by the Balfour-Browne Trust (University of Cambridge). SGC thanks Thanate Kerdkauw for drawing attention to the flies breeding in the figs he was studying in Thailand.

\section{REFERENCES}

Berg C. C. \& Corner E. J. H. 2005. Moraceae-Ficus. Flora Malesiana. Series I (Seed Plants) 17: 1-727.

BORGMEIER T. 1967. Studies on Indo-Australian phorid flies, based mainly on material of the Museum of Comparative Zoology and the United States National Museum (Diptera, Phoridae). Studia Entomologica, Petropolis 9 (1966): 129-328.

Compton S. G. \& Disney R. H. L. 1991. New species of Megaselia (Diptera: Phoridae) whose larvae live in fig syconia (Urticales: Moraceae), and adults prey on fig wasps (Hymenoptera: Agaonidae). Journal of Natural History 25: 203-219. DOI: 10.1516/R22K-4164-7744-J272

DisNeY R. H. L. 1986. Morphological and other observations on Chonocephalus (Phoridae) and phylogenetic implications for the Cyclorrhapha (Diptera). Journal of Zoology, London (A) 210: 77-87. DOI.org/10.1111/j.14697998.1986.tb03621.x

DiSNEY R. H. L. 2001. The preservation of small Diptera. Entomologist's Monthly Magazine 137: 155-159.

DiSNEY R. H. L. 2016. Review of Oriental Chonocephalus Wandolleck (Diptera: Phoridae). Annales Zoologici 66 (2): 277-328. DOI: 10.3161/00034541ANZ2016.66.2.008

Harry M., Solignac H. M. \& LAChaise D. 1997. Adaptive radiation in the Afrotropical region of the Paleotropical genus Lissocephala (Drosophilidae) on the pantropical genus Ficus (Moraceae). Journal of Biogeography 23: 543-552. DOI.org/10.1111/j.1365-2699.1996.tb00016.x

JousSELIN E. \& KJELLBERG F. 2001. The functional implications of active and passive pollination in dioecious figs. Ecology Letters 4: 151-158. DOI.org/10.1046/j.1461-0248.2001.00209.x

MACGOWAN I. \& COMPTON S. G. 2018. A new species of Silba (Diptera; Lonchaeidae) associated with figs. Zootaxa: 4455 (1): 196-200. DOI: 10.11646/zootaxa.4455.1.10

Miao B. G., YAng D. R., LiU C., Peng Y-Q. \& ComptoN S. G. 2011. The impact of a gall midge on the reproductive success of Ficus benjamina, a potentially invasive fig tree. Biological Control 59: 228-233. DOI: 10.1016/j.biocontrol.2011.07.007 
STRESZCZENIE

[Nowy gatunek Megaselia Rondani (Diptera: Phoridae) związany $z$ jedną płcią dwupiennego drzewa figowego $\mathrm{w}$ Tajlandii]

W pracy opisany został gatunek Phoridae wyhodowany $\mathrm{z}$ larw zasiedlających kwiaty dwupiennego figowca (Ficus ischnopoda Miq., Urticales, Moracea), rozprzestrzenionego w południowo-wschodniej Azji. Nowy dla nauki gatunek zadrowatych - Megaselia ischnopodae Disney n. sp. wyhodowano z larw znalezionych w dojrzałych męskich figach, które nie kryją nasion (te znajdują się w żeńskich figach), lecz służą rozwojowi właściwym zapylaczom - błonkówkom. Nowy gatunek M. ischnopodae znaleziono tam obok większych larw innego, niedawno opisanego gatunku muchówki Silba ischnopoda MacGowan, który jest prawdopodobnie drapieżnikiem zapylaczy. Larwy zadrowatych były obecne wśród kwiatów pseudożeńskich (poniżej kwiatów męskich), co sugeruje, że żywią się one martwymi i umierającymi dorosłymi samcami figowych błonkówek, a nie pyłkiem uwalnianym przez pękające pylniki. Obecność larw zadrowatych w męskich figach, w których błonkówki figowe wycięły już otwory wyjściowe, sugeruje, że mogą one przez te otwory uzyskiwać dostęp do wnętrza figi, zwłaszcza, że na zewnątrz mniej dojrzałych męskich fig obserwowano małe larwy zadrowatych przy ostioli, gdy nie było tam jeszcze otworu wyciętego przez błonkówki. 